\title{
Is There Additive Therapeutic Effect When GCSF Combined with Adipose-Derived Stem Cell in a Rat Model of Acute Spinal Cord Injury?
}

\author{
Joongkee Min, Ph.D., ${ }^{1 *}$ Jeong Hoon Kim, M.D., Ph.D., ${ }^{*}$ Kyoung Hyo Choi, M.D., Ph.D., ${ }^{2}$ Hyung Ho Yoon, Ph.D., \\ Sang Ryong Jeon, M.D., Ph.D.' \\ Departments of Neurological Surgery, Rehabilitation Medicine, ${ }^{2}$ Asan Medical Center, University of Ulsan College of Medicine, Seoul, Korea
}

Objective : Functional and neural tissue recovery has been reported in many animal studies conducted with stem cells. However, the combined effect of cytokines and stem cells has not yet been adequately researched. Here, we analyzed the additive effects of granulocyte colony-stimulating factor (GCSF) on adipose-derived stem cells (ADSCs) infusion in the treatment of acute spinal cord injury $(\mathrm{SCl})$ in rats.

Methods : Four days after intrathecal infusion tubes implantation in Sprague-Dawley rats, SCI was induced with an infinite horizon impactor. In the Sham group ( $n=5)$, phosphate-buffered saline was injected 3, 7, and 14 days after SCI. GCSF, ADSCs, and ADSCs with GCSF were injected at the same time in the GCSF $(n=8), \operatorname{ADSC}(n=8)$, and ADSC+GCSF groups $(n=7)$, respectively.

Results : The ADSC and ADSC+GCSF groups, but not the GCSF group, showed significantly higher Basso-Beattie-Bresnahan scores than the Sham group during 8 weeks $(p<0.01)$, but no significant difference between the ADSC and ADSC+GCSF groups. In the ladder rung test, all four groups were significantly different from each other, with the ADSC+GCSF group showing the best improvement $(p<0.01)$. On immunofluorescent staining (GAP43, MAP2), western blotting (GAP43), and reverse transcription polymerase chain reaction (GAP43, nerve growth factor), the ADSC and ADSC+GCSF groups showed higher levels than the Sham and GCSF groups.

Conclusion : Our analyses suggest that the combination of GCSF and ADSCs infusions in acute SCl in the rat does not have a significant additive effect. Hence, when combination agents for SCl stem cell therapy are considered, molecules other than GCSF, or modifications to the methodology, should be investigated.

Key Words : Spinal cord injury · Mesenchymal stem cell · Combined modality therapy · GAP-43 protein · Granulocyte colonystimulating factor.

- Received : October 12, 2016 •Accepted : December 9, 2016

- Address for reprints : Sang Ryong Jeon, M.D., Ph.D.

Department of Neurological Surgery, Asan Medical Center, University of Ulsan College of Medicine, 88 Olympic-ro 43-gil, Songpa-gu, Seoul 05505, Korea Tel : +82-2-3010-3550, Fax : +82-2-476-6738, E-mail : srjeon@amc.seoul.kr

* Joongkee Min and Jeong Hoon Kim contributed equally to this work.

This is an Open Access article distributed under the terms of the Creative Commons Attribution Non-Commercial License (http://creativecommons.org/licenses/by-nc/4.0) which permits unrestricted non-commercial use, distribution, and reproduction in any medium, provided the original work is properly cited. 


\section{INTRODUCTION}

Spinal cord injury (SCI) in humans leads to permanent functional deficits in the adult central nervous system ${ }^{3}$. Functional recovery can be achieved by endogenous repair mechanisms such as endogenous stem cell proliferation ${ }^{30,45}$, remyelination $^{40)}$, and neural plasticity ${ }^{2}$. However, severe SCI can cause the permanent neurological deficit. These deficits include neural cell death and axonal degeneration in the lesioned tissue ${ }^{45}$. Clinical treatment of SCI is focused on controlling the secondary damage after the occurrence of the lesion in recent days ${ }^{30)}$. However, controlling the secondary damage in the injured spinal column is not necessarily accompanied by restoration of spinal function ${ }^{40)}$. Therefore, repair strategies for SCI require the production of an amicable environment within the injured spinal cord in order to protect injured neurons from the effects of secondary damage and also to facilitate axonal regeneration ${ }^{24)}$. In recent years, many studies on the use of stem cells in animal models of SCI have been performed and both functional and neural tissue recovery have been reported ${ }^{2,6,10,21,24,36)}$.

Adult stem cells are unspecialized cells capable of long-term self-renewal and differentiation into specialized cells. They can thus be transformed into the various types of cells that comprise diverse body organs, including bones, brain, muscles, and $\operatorname{skin}^{26)}$. Adult stem cells are able to modify the proinflammatory response, reducing inhibitory effects of glial scar and promoting a permissive environment for axonal elongation $^{43,49)}$. Furthermore, undifferentiated mesenchymal stem cells (MSCs) have been applied to a clinical trial with these expected mechanisms for $\mathrm{SCl}^{30}$. Adipose tissue is a rich source of pluripotent stem cells that are similar to the MSCs from bone marrow ${ }^{16}$. Adipose-derived stem cells (ADSCs) are more useful because they are abundant and easily extractable ${ }^{13)}$. These ADSCs have shown therapeutic effects in various studies $^{7,17,35,3,3738)}$. Granulocyte colony-stimulating factor (GCSF) was developed and commercialized as an anticancer drug ${ }^{4}$. Nowadays, however, it is also reported to be a neurotrophic factor that affects the hematopoietic system, induces the formation of the nerves of the central nervous system, increases synaptic plasticity, and mobilize stem cells from bone marrow ${ }^{9,47)}$. In addition, several studies reported on the inhibitory effect of GCSF on neuronal cell death in the brain and spinal cord ${ }^{11,18,477}$.

ADSC and GCSF were reported to have a therapeutic effect in SCI independently, but the combined use of ADSCs and GCSF are not promising currently because this has not been well studied yet. Therefore, if we find a synergistic effect when using them together, it will provide clinical significance. Thus, in our present study, we hypothesized that GCSF could exert synergic effect especially by functioning as neurotrophic factor combined with the neurotrophic effect of ADSC and reducing secondary damage after SCI and analyzed with the behavioral test, immunofluorescent staining, and molecular study in a rat model of SCI.

\section{MATERIALS AND METHODS}

\section{Animals}

This study was reviewed and approved by the Institutional Animal Care and Use Committee (IACUC) Asan Institute for Life Sciences, Asan Medical Center. The committee abides by the institute of Laboratory Animal Resources (ILAR) guide (2012-02-029). Female Sprague-Dawley (SD; Orient Bio, Seongnam, Korea) rats weighing 250-280 g at the time of injury were used. Before the injury, all rats were housed at two animals per cage under simulated daylight conditions with alternating 12 hours light-dark cycles and had free access to food and water.

\section{Spinal cord injury}

We inserted the intrathecal (IT) catheters prior to SCI to confirm there was no spinal cord injury by IT catheter insertion. Four days before SCI induction, all rats underwent implantation of polyethylene tube (PE10; Becton Dickinson, Rutherford, NJ, USA) with outer diameter $0.61 \mathrm{~mm}$ (inner diameter : $0.28 \mathrm{~mm}$ ) to receive IT stem cell infusion. Prior to implant surgery, rats were administered with inhalation anesthesia using 2\% isoflurane (Hana Pharm, Hwaseong, Korea). The IT catheters were inserted through cisterna magna to avoid spinal cord damage and pushed $30 \mathrm{~mm}$ downwardly. After tube implantation, the external tube tip was closed and sterilized with an alcohol lamp and remained embedded in the subcutaneous layer. We applied IT catheters to all groups including Sham group to avoid the interferences caused by the catheter surgery. Among the rats, motor deficits occurred immediately after IT catheter insertion in two rats, which were excluded in this experiment. After four days of observation 
period on the wound healing and recovery from the stress of catheter insertion, the vertebral column was exposed between T7 and T8 under the same inhalation anesthesia, and a bilateral dorsal laminectomy was performed at T7 without rupturing the dura. A spinal cord contusion injury was induced by a 200 kdyn force through the use of an infinite horizon (IH) impactor (Precision System and Instrumentation, Fairfax, VA, USA). After SCI induction, the skin was primarily closed, and rats were given a prophylactic subcutaneous injection of cefazolin $(10 \mathrm{mg} / \mathrm{kg})$. For pain management, all animals were subcutaneously injected with ketoprofen $(5 \mathrm{mg} / \mathrm{kg}$ ) once daily for three days. After injury induction, the rats were housed individually in the same pre-injury environment. Bladders were emptied manually twice a day until spontaneous control of urination returned.

\section{Cell preparation}

All cell lines were provided by Prostemics (Seoul, Korea). 10 $\mathrm{g}$ of fat tissue was harvested from the bilateral inguinal area of the rat. Harvested fat tissue was washed in saline and digested in $0.075 \%$ collagenase type II (Sigma-Aldrich, St. Louis, MO, USA; filtered with a $0.20 \mu \mathrm{m}$ syringe filter) at $37^{\circ} \mathrm{C}$ for 1 hour. The harvested fat tissue was treated with an equal volume of low-glucose Dulbecco's modified Eagle's medium (DMEM; Gibco, Rockville, MD, USA) containing 10\% fetal bovine serum (Gibco) and 1\% penicillin/streptomycin (Gibco). Cells were collected by centrifugation for $10 \mathrm{~min}$ at $600 \times \mathrm{g}$, and the supernatant was discarded. The pellet was re-suspended in $160 \mathrm{mM}$ ammonium chloride (Sigma-Aldrich) and incubated for $3 \mathrm{~min}$ at room temperature. ADSCs were isolated by mash filtration $(70 \mu \mathrm{m}$ nylon mesh filter) and centrifuged at $600 \times \mathrm{g}$ for 10 minutes. The pellet was suspended in a $75 \mathrm{~cm}^{2}$ flask (Nunc, Rochester, NY, USA) as the primary culture and incubated at $37^{\circ} \mathrm{C}$ under $5 \% \mathrm{CO}_{2}$. Non-adherent cells were removed by replacing the medium. Cells were fed every 3 days with $10 \mathrm{~mL}$ of complete DMEM media. When this primary culture of ADSCs reached $80 \%$ confluence, cells were harvested using $0.25 \%$ trypsin-EDTA and washed in $10 \mathrm{~mL}$ of phosphate-buffered saline (PBS). Cell viability was assessed by Trypan blue staining.

ADSCs of passage 3 cultured in a control medium for 48 hours prior to analysis were incubated with monoclonal PEconjugated antibodies for CD34 and CD45 (BD Pharmingen, San Diego, CA, USA) or with FITC conjugated antibodies for
CD73 and CD105 (BD Pharmingen) for 30 minutes at room temperature. As a control, cells were stained with isotype control IgG. All the cells stained with antibodies were subsequently washed with PBS, fixed with $4 \%$ formaldehyde, and analyzed on a FACScan flow cytometer (Beckton Dickson, San Jose, CA, USA) using CELL Quest Pro software.

\section{GCSF injection and cell transplantation}

Three days after the induction of cord injury, the rats were divided into four groups. Human recombinant GCSF (5 $\mu \mathrm{g} / 100 \mathrm{~g}$; Dong-A, Seoul, Korea) was injected via the tail vein in the GCSF group ( $n=8)$. ADSCs $\left(1 \times 10^{7}\right.$ cells) in $50 \mu \mathrm{L}$ of PBS were infused via the IT tube in the ADSC group $(n=8)$, and IT ADSCs infusion with intravenous GCSF injection was performed in the ADSC+GCSF group $(n=7)$. In the Sham group $(n=5)$, PBS $(50 \mu \mathrm{L})$ was injected via the IT tube. GCSF was injected in GCSF and ADSC+GCSF groups at 3, 7, and 14 days after SCI. ADSCs were infused in ADSC and ADSC+GCSF groups at 3, 7, and 14 days after SCI. During each cell infusion, the animals were anesthetized and the external tip of the IT tube was re-exposed (Fig. 1). The ADSCs were infused at a rate of $10 \mu \mathrm{L}$ per minute. After ADSCs infusion, the external tube tip was closed and sterilized with an alcohol lamp. The surgical site was then re-closed.

\section{Behavioral testing}

Open field testing procedures for Basso-Beattie-Bresnahan (BBB) locomotor rating scale were performed for all rat groups as previously described ${ }^{1,3,8,43)}$. Before these tests, each animal was allowed to adapt to a treadmill $(0.15 \mathrm{~m} / \mathrm{s})$. Once a rat demonstrated acclimatization by walking continuously on the treadmill, locomotor performance was recorded with a video

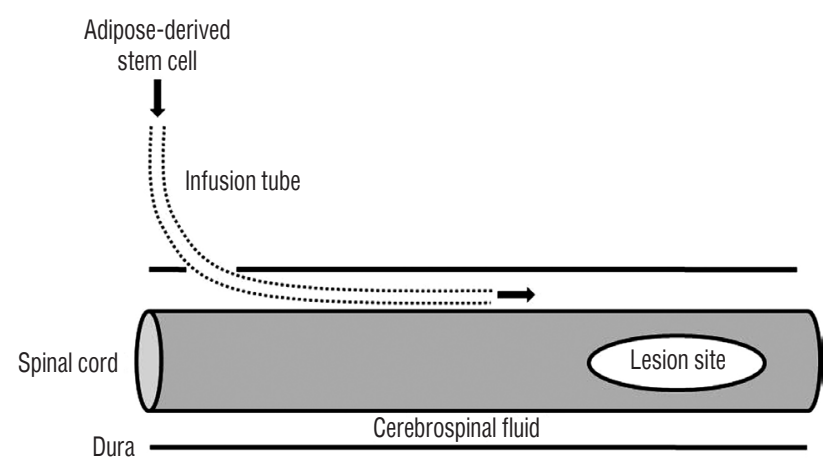

Fig. 1. Diagram of intrathecal infusion catheter implantation. 
camera for about 5 minutes. An examiner who was blind to any group-identifying information used the video to quantitatively assess the locomotor performance of each rat according to the BBB scale. Tests were performed on the 1st, 2nd, and 3rd day after the injury, and then weekly for 8 weeks. Ladder rung tests were performed on a $1.2 \mathrm{~m}$ runway. A total of 80 rungs (bars) of $0.5 \mathrm{~cm}$ in diameter and separated by $1.5 \mathrm{~cm}$ were installed. The number of adequate steps for every ten steps on the bars was and the evaluation was repeated three times. Tests were performed weekly for 8 weeks after SCI.

\section{Immunofluorescent study}

Eight weeks after SCI, all rats were sacrificed and perfused with PBS and 4\% paraformaldehyde (PFA; Sigma-Aldrich). Twenty millimeters length of spinal cords centered on the lesion site were extracted and fixed with 4\% PFA for 6 hours followed by incubation with 30\% sucrose in PBS overnight. Serial longitudinal sections with $10 \mu \mathrm{m}$ thickness of the spinal cord were obtained in every $50 \mu \mathrm{m}$ with a cryotome (Microm, Walldorf, Germany) and mounted on poly-L-lysine-coated Superfrost Plus slides (Matsunami, Osaka, Japan). The sections were washed three times with Tris-buffered saline (TBS), then blocked with TBS containing 5\% bovine serum albumin and $0.1 \%$ Triton X-100 for 1 hour at room temperature. The sections were incubated overnight with primary antibody at $4^{\circ} \mathrm{C}$, washed three times with TBS, and then incubated with the fluorescent-conjugated secondary antibody (1 : 1000; Invitrogen, Carlsbad, CA, USA). As primary antibodies, monoclonal antibodies against growth associated protein 43 (GAP43, 1 : 200; Abcam, Cambridge, UK), microtubule-associated protein 2 (MAP2, $1: 200$; Abcam), and choline acetyltransferase (ChAT, $1: 200$; Abcam) were used. Sections were observed under a fluorescence microscope (Carl Zeiss Meditec, Jena, Germany).

\section{Western blotting}

Injury epicenters of $0.5 \mathrm{~cm}$ in size, harvested 8 weeks after SCI, were lysed by homogenization in $300 \mu \mathrm{L}$ lysis buffer containing $20 \mathrm{mM}$ Tris $\mathrm{pH}$ 7.4, $50 \mathrm{mM} \mathrm{NaCl}_{2}, 1 \%$ Triton X-100, and protease inhibitor (Intron, Seoul, Korea). Debris was cleared by centrifugation, and supernatants were aliquoted and stored at $-80^{\circ} \mathrm{C}$. Samples were assayed for protein concentration with a bicinchoninic acid assay (Thermo Scientific, Rockford, IL, USA). After heating at $100^{\circ} \mathrm{C}$ for 5 minutes in 5 $\times$ sample buffer, equal amounts of denatured protein $(30 \mu \mathrm{g})$ were separated by SDS-polyacrylamide gel electrophoresis on $10 \%$ gels and transferred onto polyvinylidene difluoride membranes at $20 \mathrm{~V}$ for 7 minutes with an iBlot ${ }^{\circledR}$ gel transfer device (Invitrogen). After incubating for 1 hour at room temperature with blocking solution (0.4\% Tween-20 and 5\% dry milk in PBS), membranes were incubated overnight with primary antibodies against serotonin transporter (1 : 1000; Abcam), acetylcholine receptor (1: 1000; Abcam), or GAP43 (1 : 500; Abcam); an antibody against $\beta$-actin (1 : 10000; SigmaAldrich) was used as a control for equal loading. After washing with $0.1 \%$ Tween-20/TBS, blots were incubated with horseradish peroxidase-conjugated secondary antibodies (Sigma-Aldrich) and then developed with enhanced chemiluminescence reagents (Pierce Biotechnology, Rockford, IL, USA).

\section{Reverse transcription polymerase chain reaction (RT-PCR)}

For RNA isolation, $1 \mathrm{~mL}$ TRIzol ${ }^{\circledR}$ reagent (Invitrogen) was added per $100 \mathrm{mg}$ of spinal cord specimen, homogenized with a pestle and mortar and liquid nitrogen, and washed with $1 \mathrm{~mL}$ diethylpyrocarbonate-treated water (Invitrogen). Homogenized samples were incubated for 5 minutes at room temperature and $200 \mu \mathrm{L}$ of chloroform (Sigma-Aldrich) was added per $1 \mathrm{~mL}$ of TRIzol ${ }^{\circledR}$ reagent. The samples were vigorously hand shaken for 15 seconds, incubated for 3 minutes, and divided following centrifugation at $12000 \times \mathrm{g}$ for 10 minutes at $4^{\circ} \mathrm{C}$. The aqueous phase was transferred to a fresh tube $(1.5 \mathrm{~mL})$ and $500 \mu \mathrm{L}$ of isopropyl alcohol (Sigma-Aldrich) was added per $1 \mathrm{~mL}$ of TRIzol $^{\circledR}$ reagent. The samples were incubated at room temperature for 10 minutes and centrifuged at $12000 \times \mathrm{g}$ for 10 minutes at $4^{\circ} \mathrm{C}$. The RNA was washed by centrifugation at $7500 \times \mathrm{g}$ for 5 minutes at $4^{\circ} \mathrm{C}$ after supernatant removal and $1 \mathrm{~mL}$ of $75 \%$ ethanol was added per $1 \mathrm{~mL}$ of TRIzol ${ }^{\circledR}$ reagent. The RNA pellet was briefly dried and the RNA was dissolved in RNase-free water and incubated for 10 minutes at $60^{\circ} \mathrm{C}$. The cDNA mixture was incubated at $65^{\circ} \mathrm{C}$ for 5 minutes, placed on ice for 1 minute, and then incubated at $50^{\circ} \mathrm{C}$ for 50 minutes in the following cDNA synthesis mixture: $2 \mu \mathrm{L} 10 \times$ reverse transcriptase buffer, $4 \mu \mathrm{L} 25 \mathrm{mM} \mathrm{MgCl}$, $2 \mu \mathrm{L} 0.1$ M DTT, $1 \mu \mathrm{L}$ RNase $\mathrm{OUT}^{\mathrm{TM}}$ (40 U/ $\mu \mathrm{L}$; Invitrogen), and $1 \mu \mathrm{L}$ Superscript ${ }^{\mathrm{TM}}$ III RT (200 U/ $\mu \mathrm{L}$; Invitrogen). The mixture was placed at $85^{\circ} \mathrm{C}$ for 5 minutes, chilled on ice, and then briefly centrifuged. Following the addition of $1 \mu \mathrm{L}$ of RNase $H$, the sample was incubated for 20 minutes at $37^{\circ} \mathrm{C}$. For the PCR mixture, sense and antisense 
primers (Table 1), template DNA, and distilled water were used. After the PCR reaction, correct band amplification was confirmed by agarose electrophoresis.

\section{Data processing and statistical analyses}

The results of behavior scores and molecular biological test in all four groups were analyzed by one-way analysis of vari-

Table 1. Primers used in this study

\begin{tabular}{lllc}
\hline Primer & & \multicolumn{1}{c}{ Sequence $\left(\mathbf{3}^{\prime} \mathbf{- 5}^{\prime}\right.$ ) } & Size \\
\hline 3-actin & Sense & GGTATGGGTCAGAAGGACTCC & 801 bp \\
& Antisense & CCTGTCAGCAATGCCTGGGTA & \\
GAP43 & Sense & GATAAGGCTCATAAGGCTGC & $401 \mathrm{bp}$ \\
& Antisense & CCTAAACAAGCCGATGTGCC & \\
NGF & Sense & TGCCCCTGCTGAACCAATAGC & $496 \mathrm{bp}$ \\
& Antisense & AGCCTGTTTGTCGTCTGTTGT & \\
\hline
\end{tabular}

NGF : nerve growth factor
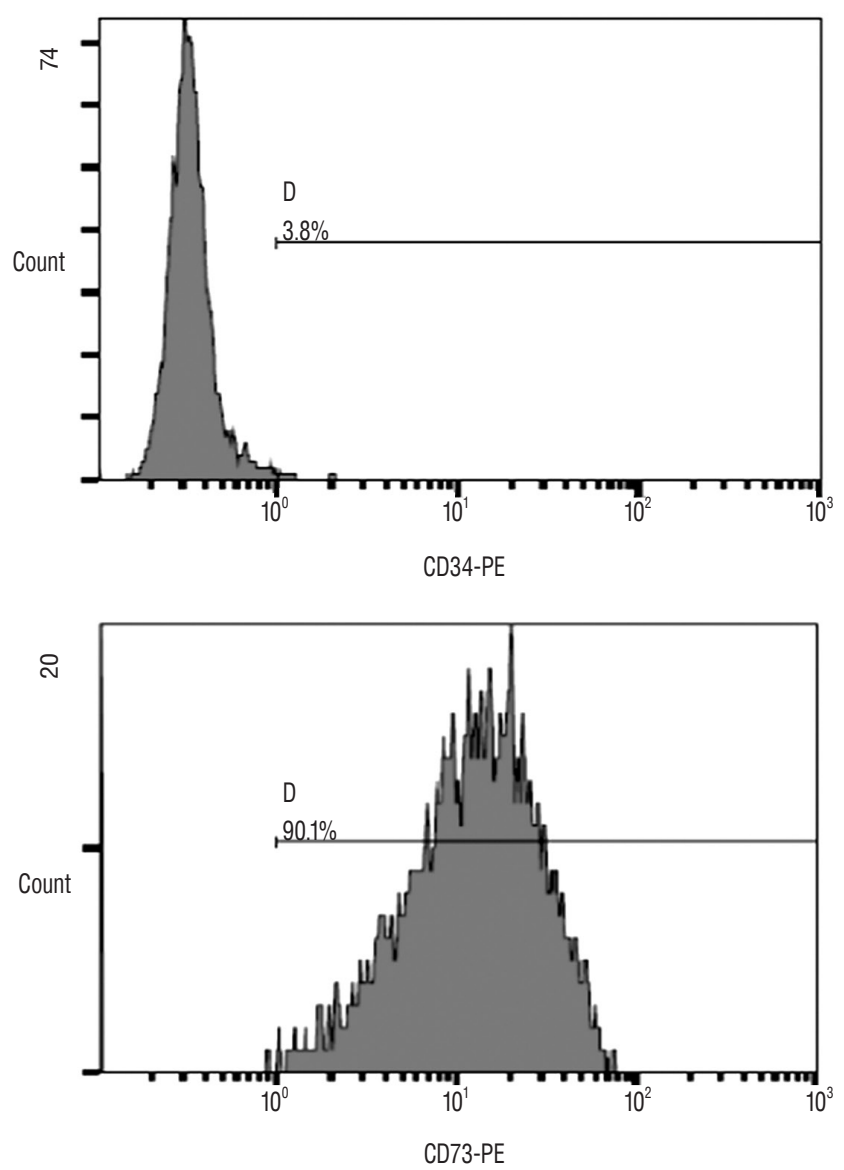

ance followed by a posthoc Tukey-Kramer multiple comparison tests. Data are expressed as the mean \pm standard deviation. All statistical analyses were performed with SPSS statistical software (version 12.0.1; SPSS Inc., Chicago, IL, USA).

\section{RESULTS}

\section{Characterization of ADSCs}

ADSCs expanded easily in vitro by culturing and exhibited a fibroblast-like morphology. In flow cytometry, characteristic expressions of stem cell related surface markers were confirmed. ADSCs expressed CD73 and CD105 which are adipogenic mesenchymal stem cell markers in $90.1 \%$ and $98.6 \%$, respectively and were negative in CD34 and CD45 representing hematopoietic stem cell markers in $96.2 \%$ and $99.4 \%$, respectively (Fig. 2) ${ }^{38)}$.
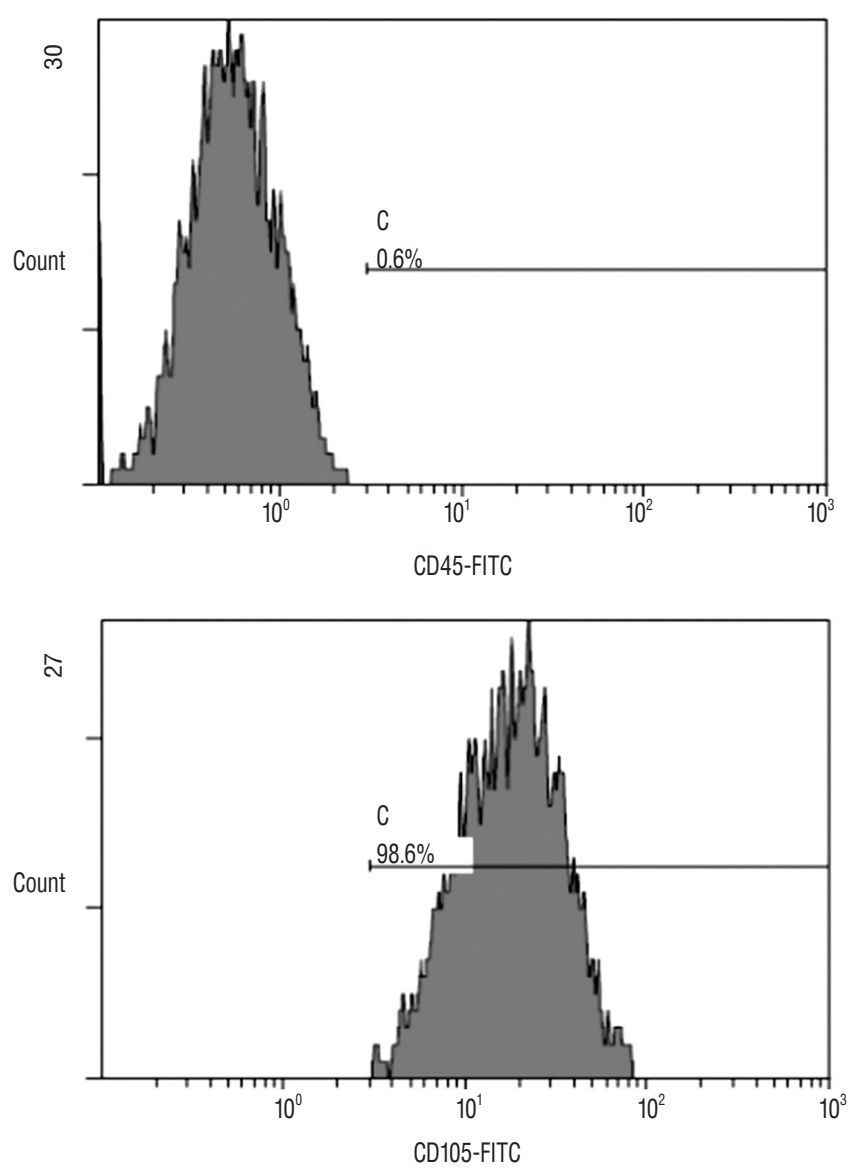

Fig. 2. Flow cytometric histograms of rat ADSCs by FACScan flow cytometer (Beckton Dickson, San Jose, CA, USA). Adipogenic positive marker, CD73, and CD105 were expressed in $90.1 \%$ and $98.6 \%$, respectively. Adipogenic negative marker, CD34, and CD45 were indicated as $3.8 \%$ and $0.6 \%$, respectively. ADSC : adipose-derived stem cell. 


\section{Behavior tests}

Eight weeks after SCI, rats in the ADSC and ADSC+GCSF groups achieved mean BBB scores of $17.37 \pm 0.7$ and $17.57 \pm 0.5$, respectively, which were significantly higher than the GCSF and Sham group BBB scores of $16 \pm 0.5$ and $15.6 \pm 0.5$, respectively ( $p<0.01$; Fig. 3 ). There was no significant difference found between the BBB scores of the ADSC and ADSC+GCSF groups. The rats of the GCSF group did not show significantly higher score than that of the Sham group. In the ladder rung test, rats in the ADSC+GCSF group achieved a success rate of $70 \pm 2.8 \%$, which was significantly higher than that of the Sham (52 $\pm 3.2 \%)$, GCSF (62.5 $\pm 3.7 \%)$, and ADSC (66.2 $\pm 4.6 \%)$ groups $(p<0.01$; Fig. 4$)$.

\section{Immunofluorescent study}

Confocal microscope analysis showed that GAP43 immunoreactivity in the injured spinal cords of the rats was higher in the ADSC and ADSC+GCSF groups than in the Sham and GCSF groups at 8 weeks after SCI (Fig. 5). For the other axonal

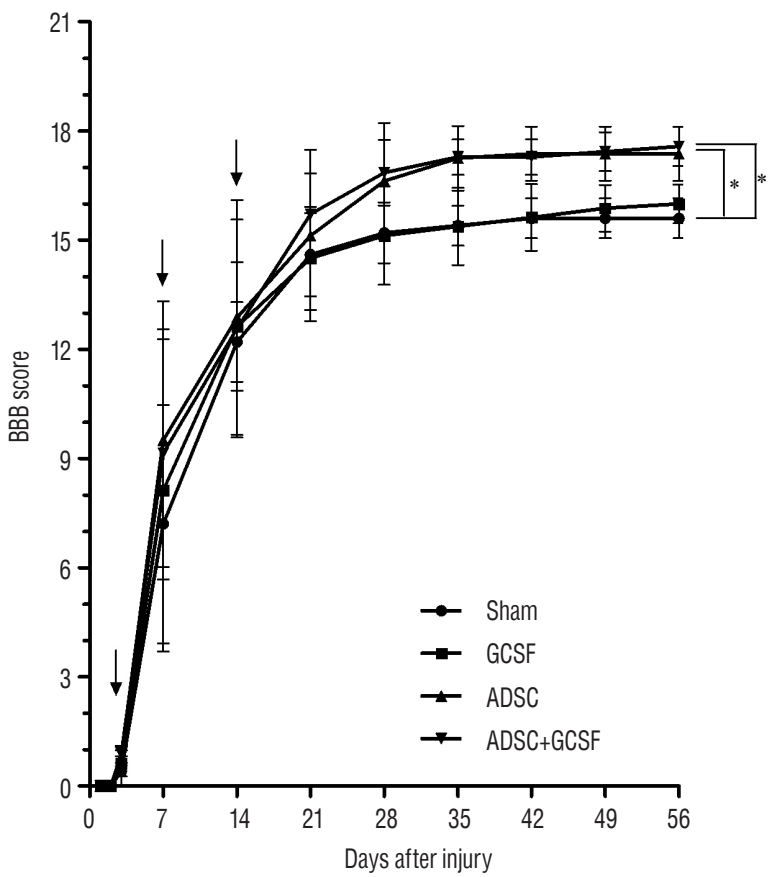

Fig. 3. BBB locomotor scale test. The recovery of BBB locomotor function after $\mathrm{SCl}$ in rats treated by infusion with PBS (Sham group), injection with GCSF (GCSF group), infusion with ADSCs (ADSC group), or infusion with $A D S C s$ and GCSF (ADSC+GCSF group). Black arrow is injection time point. ${ }^{*} p<0.01$. BBB : Basso-Beattie-Bresnahan, $\mathrm{SCl}$ : spinal cord injury, PBS : phosphate-buffered saline, GCSF : granulocyte colony-stimulating factor, ADSC : adipose-derived stem cell. regeneration marker, MAP2, microscope analysis showed higher MAP2 immunoreactivity in the injured spinal cord in the ADSC and ADSC+GCSF groups than in the Sham and GCSF groups 8 weeks after SCI (Fig. 6). There was no difference found between the ADSC and ADSC+GCSF groups. In addition, the immunoreactivity of the motor neuron marker, ChAT, in the injured spinal cord was higher in the ADSC+GCSF group than in the other three groups 8 weeks after SCI (Fig. 7).

\section{Western blotting}

After western blotting, the relative density levels (RDLs, $\mathrm{OD} / \mathrm{mm}$ ) of the protein bands were measured in all of the SCI groups. For the serotonin transporter, the ADSC group had a significantly higher RDL than the Sham group (2.45 \pm 0.07 vs. $2.24 \pm 0.08$, respectively; $p<0.05)$. The ADSC+GCSF group ( 2.4 \pm 0.03 ) had a higher RDL than the Sham group, but the difference was not statistically significant $(p=0.7)$. The GCSF group had a lower RDL (2.05 \pm 0.03 ; Fig. 8). For the acetylcholine receptor, the ADSC group had a significantly higher RDL than the Sham group $(2.35 \pm 0.02$ vs. $1.75 \pm 0.2 ; p<0.01)$, whereas the ADSC+GCSF (2.05 \pm 0.03$)$ and GCSF $(1.8 \pm 0.001)$ groups had an insignificantly higher RDL than the Sham group $(p>0.4$; Fig. 9). For GAP43, the three experimental groups particularly

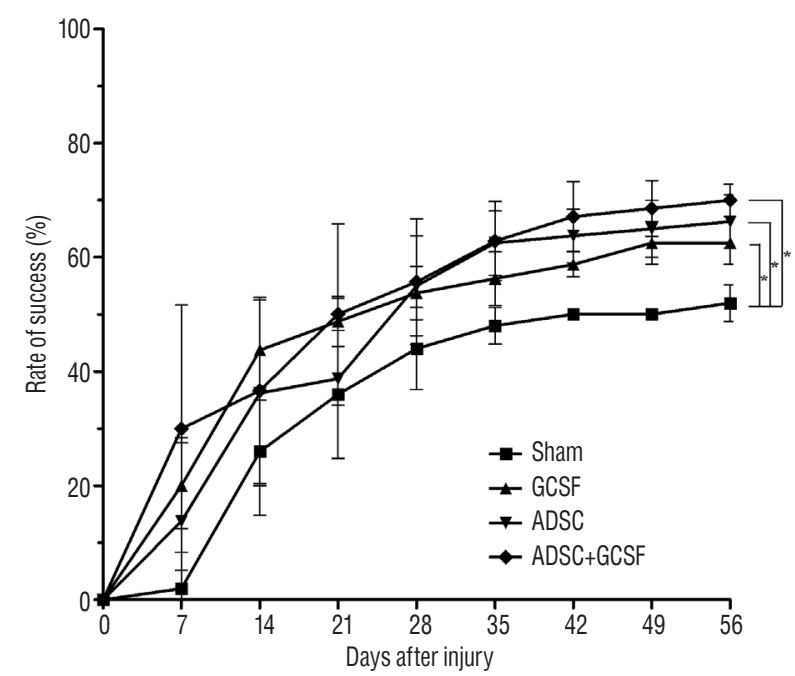

Fig. 4. Ladder rung test. The recovery of hindlimb function after $\mathrm{SCl}$ in rats treated by infusion with PBS (Sham group), injection with GCSF (GCSF group), infusion with ADSCs (ADSC group), or infusion with ADSCs and GCSF (ADSC+GCSF group). ${ }^{*} p<0.01$. $\mathrm{SCl}$ : spinal cord injury, PBS : phosphate-buffered saline, GCSF : granulocyte colony-stimulating factor, ADSC : adipose-derived stem cell. 


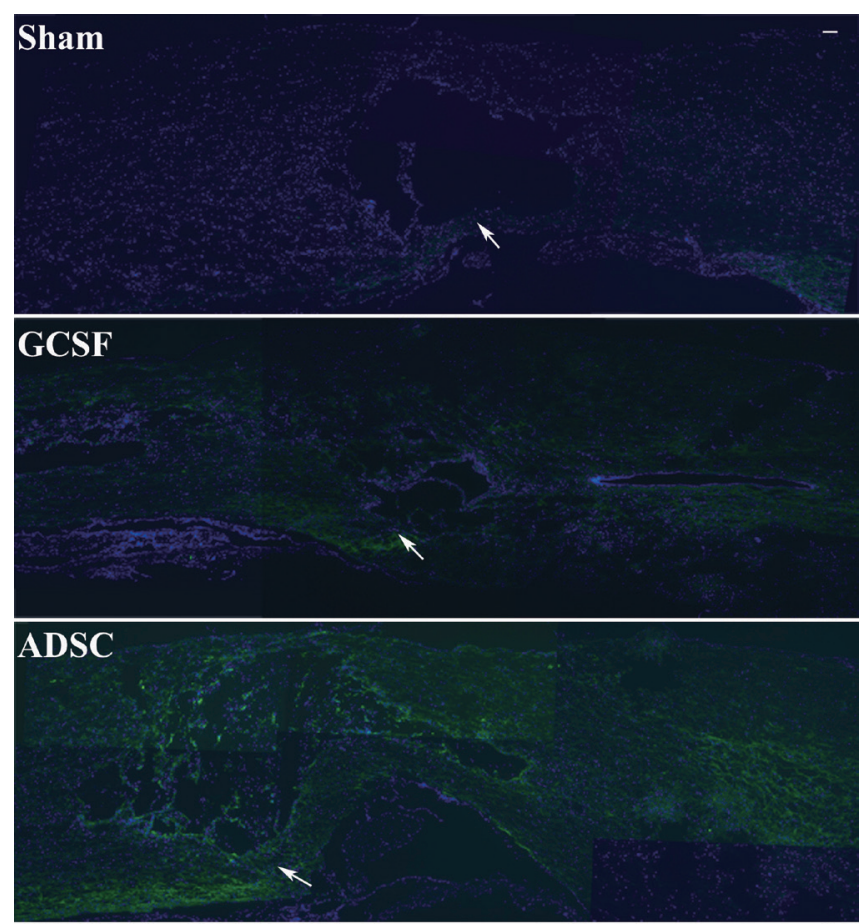

\section{ADSC+GCSF}

A (x)

the ADSC $(0.78 \pm 0.001)$ and ADSC+GCSF $(0.76 \pm 0.01)$ groups $(p<0.01)$ had higher RDLs than the Sham group $(0.17 \pm 0.001$; Fig. 10).

\section{Reverse transcription polymerase chain reaction (RT-PCR)}

RT-PCR results were evaluated in the same way as the western blotting data. For GAP43 gene expression, the ADSC (12.05 \pm 0.17$)$ and ADSC+GSCF (16.14 \pm 0.06$)$ groups had significantly higher RDLs than the Sham group (7.83 \pm 0.11 ; $p<0.01$; Fig. 11). However, the GAP43 level of the GCSF group $(7.77 \pm 0.3)$ was not significantly different from that of the Sham group. For nerve growth factor (NGF) gene expression, the ADSC (3.38 \pm 0.11$)$ and ADSC+GSCF $(3.77 \pm 0.05)$ groups had significantly higher RDLs than the Sham group (2.22 \pm $0.08 ; p<0.01$; Fig. 12). However, there was no significant difference between the RDLs of the GCSF $(2.19 \pm 0.02)$ and Sham groups.

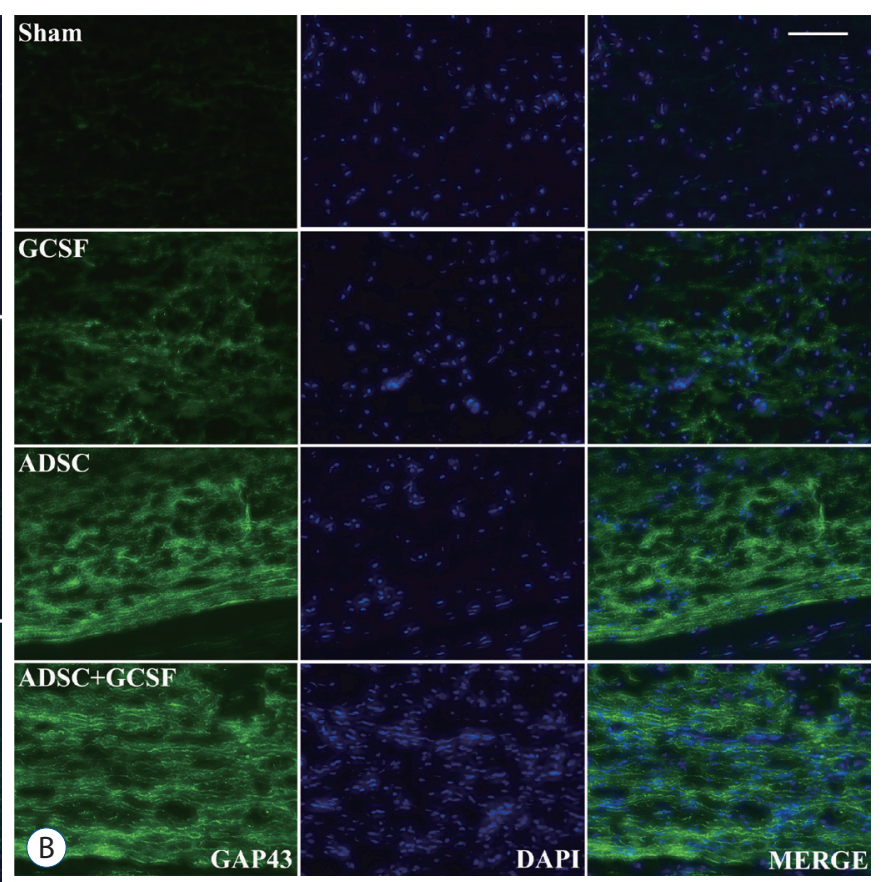

Fig. 5. Histological assessment of axonal regeneration using a GAP43. A : Confocal microscopic pictures revealed that anti-GAP43 antibody staining in the spinal cord was greater in the ADSC and ADSC+GCSF groups than in the Sham or GCSF groups 8 weeks after SCI. B : Magnification of white arrow area from (A). Scale bar: $50 \mu \mathrm{m}$. ADSC : adipose-derived stem cell, GCSF : granulocyte colony-stimulating factor.

\section{DISCUSSION}

The rodent injury model is very widely used in the SCI research field ${ }^{42)}$. In our present study, we conducted an animal model of traumatic SCI by using an IH impactor (Precision System and Instrumentation), which can produce more consistent SCI ${ }^{12,39,46)}$ compared to the New York University (NYU) impactor (New York University, New York, NY, USA). The NYU impactor has been a widely used contusion device that generates contusion with weight-drop $\operatorname{rod}^{23,28)}$, but it requires an experienced person to generate a successful contusion because there's a difficulty controlling the impactor. We applied 200 kdyn impacts to create the moderate SCI which is compatible with 10-gram rod drop from $25 \mathrm{~mm}$ height by NYU impactor (unpublished data). Moderate SCI is a suitable condition of animal experiment because severe SCI $(50 \mathrm{~mm}$ height by NYU impactor) might be difficult to manage the animals as high mortality, and mild SCI (12.5 mm height by 


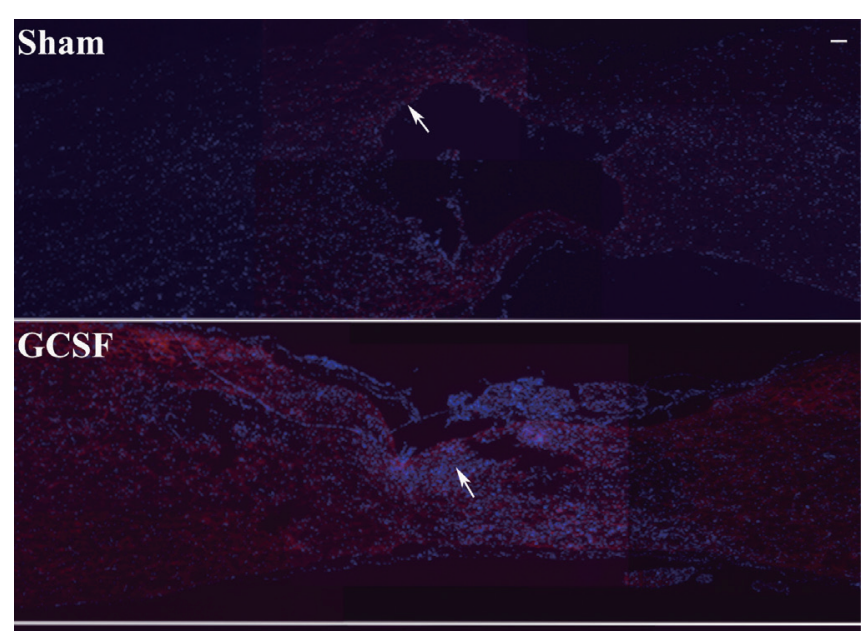

\section{ADSC}

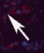

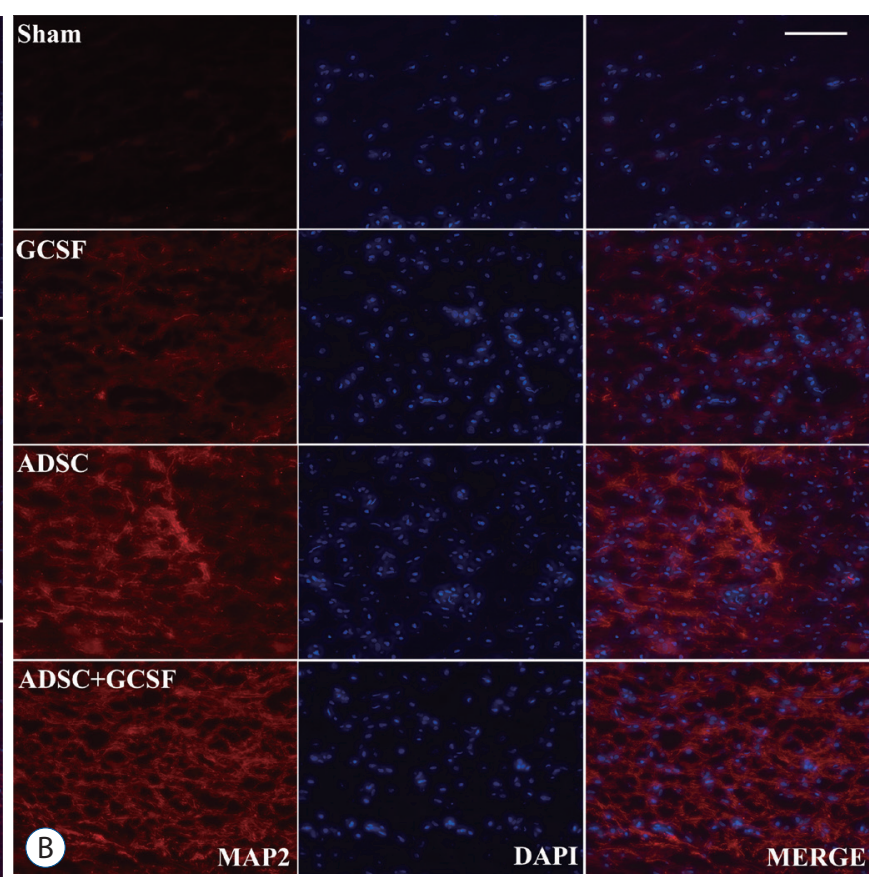

Fig. 6. Histological assessment of axonal regeneration using an MAP2. A : Confocal microscopic pictures revealed that anti-MAP2 antibody staining in the spinal cord was greater in the ADSC and ADSC+GCSF groups than in the Sham or GCSF groups 8 weeks after SCI. B : Magnification of white arrow area from (A). Scale bar: $50 \mu \mathrm{m}$. ADSC : adipose-derived stem cell, GCSF : granulocyte colony-stimulating factor, $\mathrm{SCl}$ : spinal cord injury, DAPI : 4',6-diamidino-2'-phenylindole.

poietic stem cells from the bone marrow into the peripheral blood" and it has been used extensively for bone marrow reconstitution and stem cell mobilization ${ }^{25)}$. In addition, the systemic administration of GCSF enhanced the availability of circulating hematopoietic stem cells to the brain, resulting neurogenesis in cerebral ischemia ${ }^{41)}$, and induced neurite outgrowth in hippocampus as well as increased axonal conduction demonstrated by mangan-enhanced magnetic resonance imaging and biotinylated dextran amine tracing ${ }^{32)}$.

GCSF is usually administered systemically (intravenous or subcutaneous) to stimulate bone marrow ${ }^{18,47}$, and we also injected GCSF via tail vein to achieve the same mechanism. On the contrary, stem cells are administered through a local application such as intramedullary or intrathecal injections because stem cells function locally including filling the contused cavity mechanically or forming a matrix to bridge for axon regeneration through the cavity as we reported previously ${ }^{30,43)}$. Also, intrathecal injection of stem cells is a clinically well-established method ${ }^{20,29,30)}$. Therefore, we think intravenous 

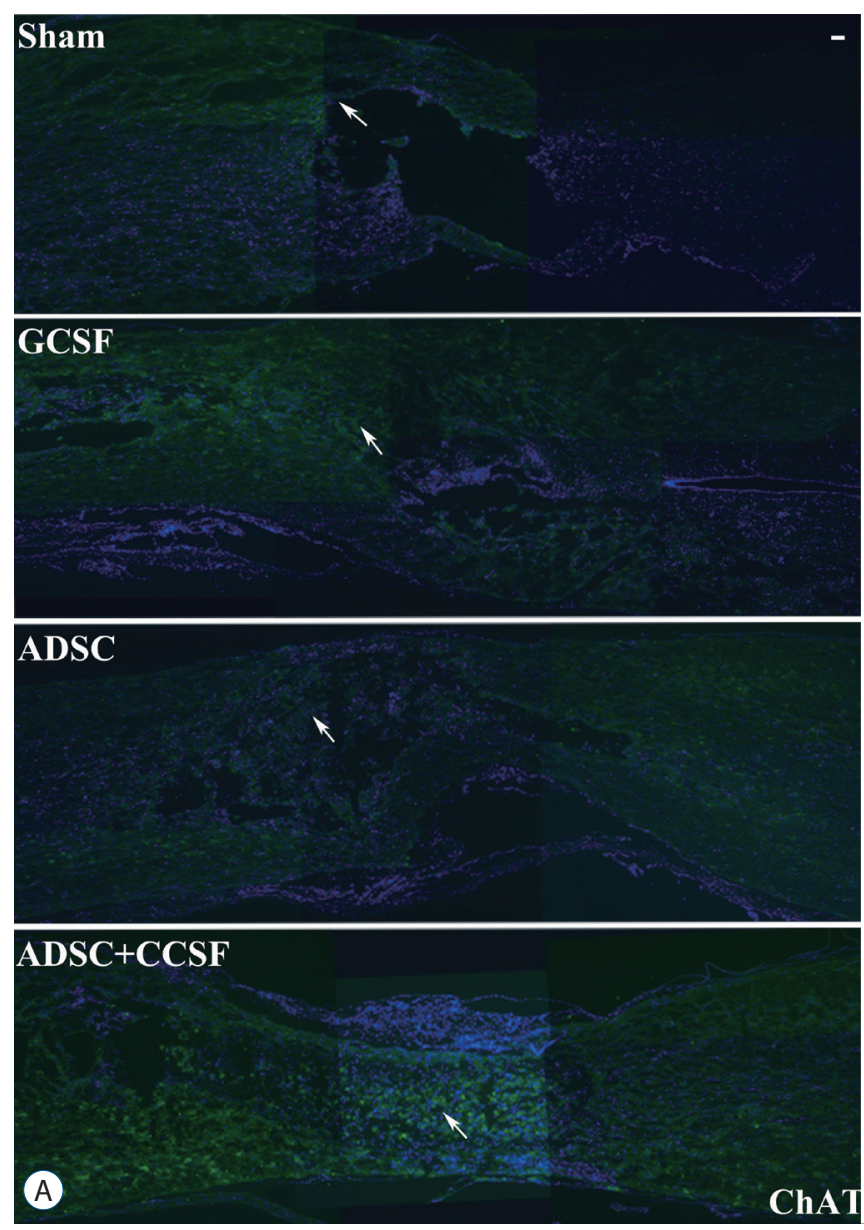

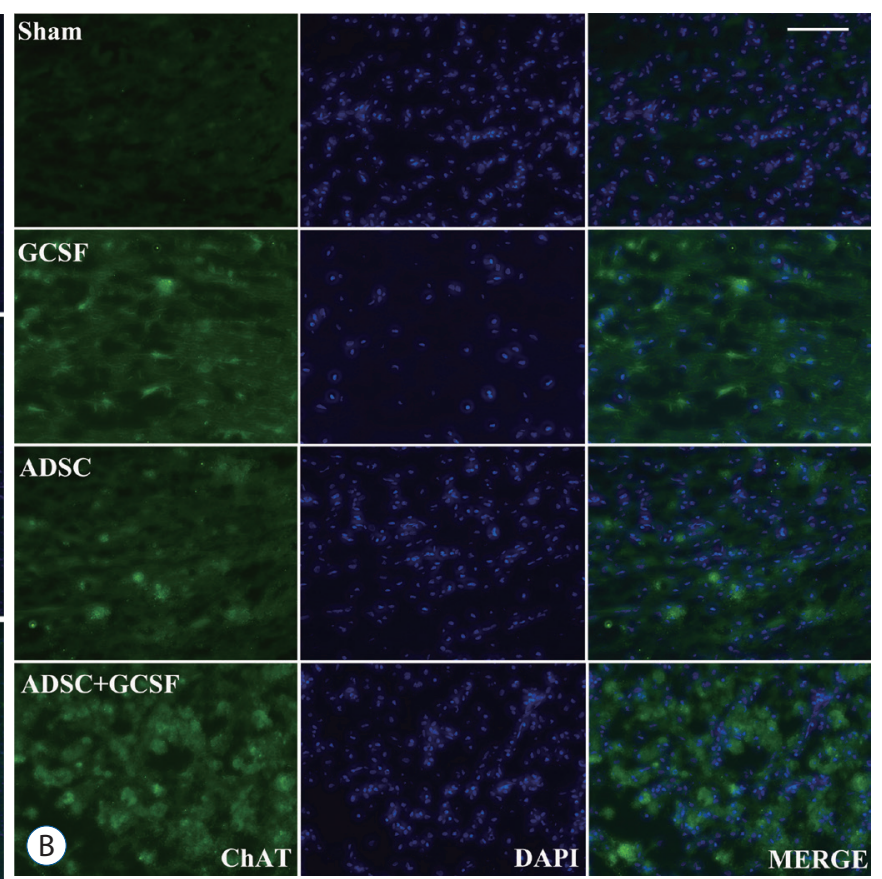

Fig. 7. Histological assessment of motor neuron marker using a ChAT. A : Confocal microscopic pictures revealed that anti-ChAT antibody staining in the spinal cord was greater in the ADSC+GCSF group than in other groups 8 weeks after SCl. B : Magnification of white arrow area from (A). Scale bar : $50 \mu \mathrm{m}$. GCSF : granulocyte colony-stimulating factor, ADSC : adipose-derived stem cell, $\mathrm{SCl}$ : spinal cord injury, DAPI : 4',6-diamidino-2'phenylindole.
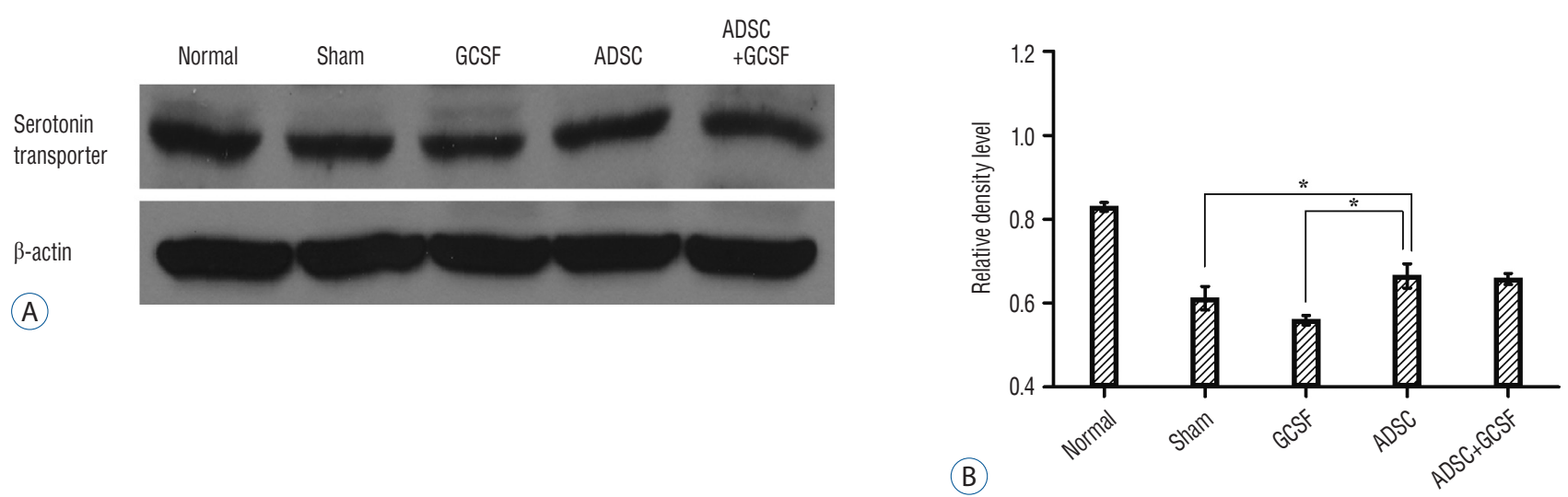

Fig. 8. Western blots analysis of serotonin transporter. A : Injured epicenters of $0.5 \mathrm{~cm}$ spinal cord were extracted protein and analyzed by Western blots. B : When the band densities were converted into RDL value, the ADSC group showed significantly high density than Sham and GCSF groups. There was no statistical difference of RDL value between the ADSC and ADSC+GCSF groups. ${ }^{*} p<0.05$. RDL : relative density level, ADSC : adipose-derived stem cell, GCSF : granulocyte colony-stimulating factor.

GCSF injection with intrathecal stem cell administration is most appropriate to verify the effectiveness of combined application and designed the study using this method.

In previous studies, GCSF is used in a dose range from
$0.5-5 \mu \mathrm{g} / 100 \mathrm{~g}$ systemically in rats for the treatment of contusive $\mathrm{SCI}^{18,47)}$. In this study, we performed injection of GCSF $(5 \mu \mathrm{g} / 100 \mathrm{~g})$ via tail vein which is the most common and maximal dose reported for SCI study. GCSF dose in this 


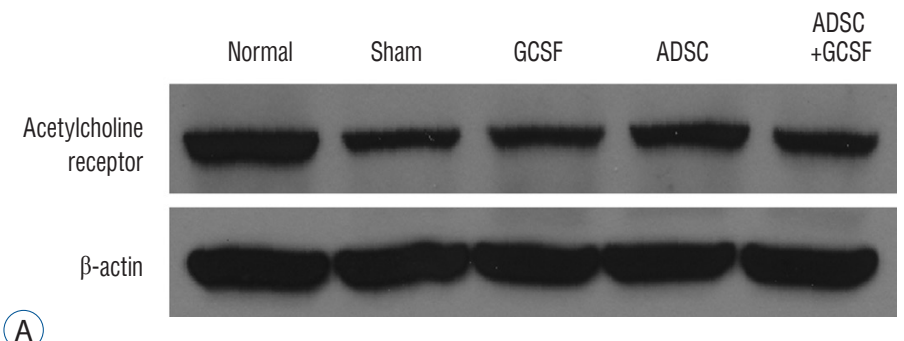

(B)

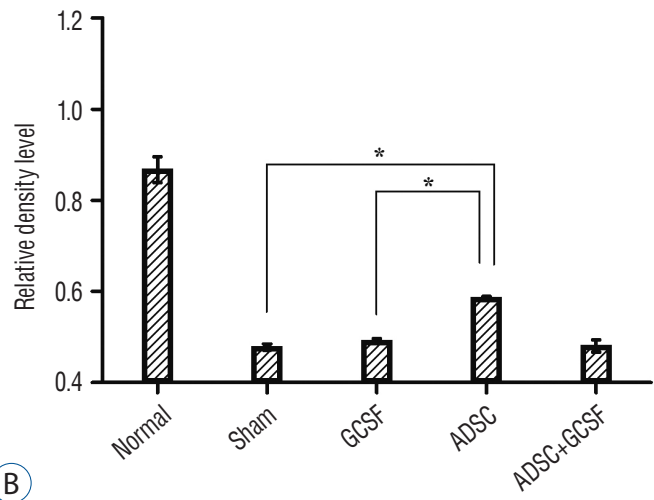

Fig. 9. Western blots analysis of acetylcholine receptor. A : Injured epicenters of $0.5 \mathrm{~cm}$ spinal cord were extracted protein and analyzed by Western blots. $\mathrm{B}$ : When the band densities were converted into RDL value, the ADSC group showed significantly high density than other groups. ${ }^{*} p<0.01$. RDL : relative density level, ADSC : adipose-derived stem cell, GCSF : granulocyte colony-stimulating factor.

\section{(A)}

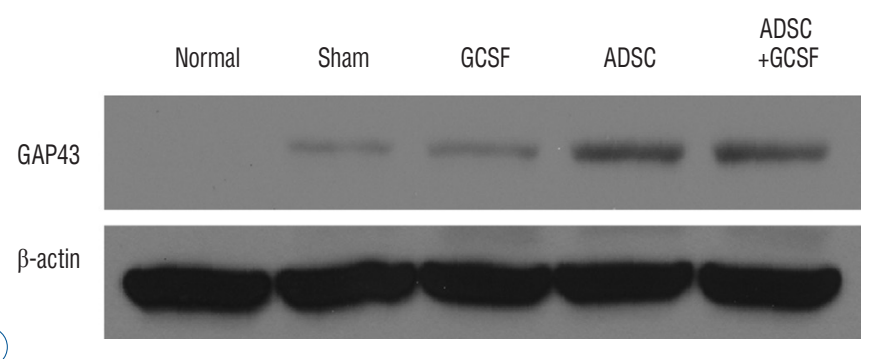

(B)

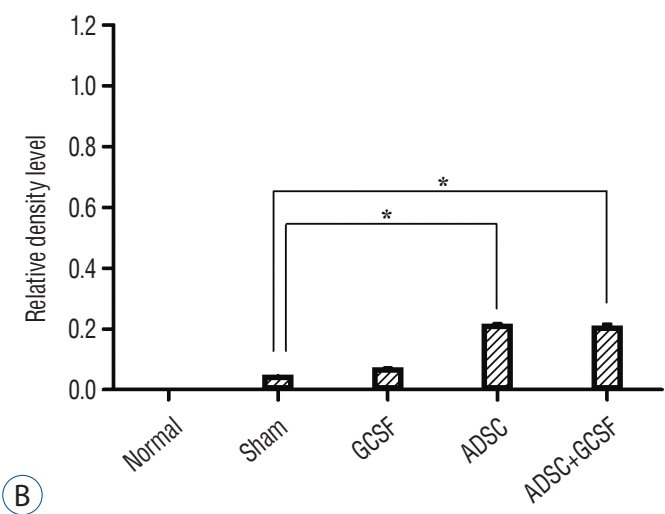

Fig. 10. Western blots analysis of GAP43. A : Injured epicenters of $0.5 \mathrm{~cm}$ spinal cord were extracted protein and analyzed by Western blots. B : When the band densities were converted into RDL value, the ADSC and ADSC+GCSF groups showed significantly high density than the Sham and GCSF groups. There was no statistical difference of RDL value between the ADSC and ADSC+GCSF groups. * $p<0.01$. RDL : relative density level, ADSC : adipose-derived stem cell, GCSF : granulocyte colony-stimulating factor.
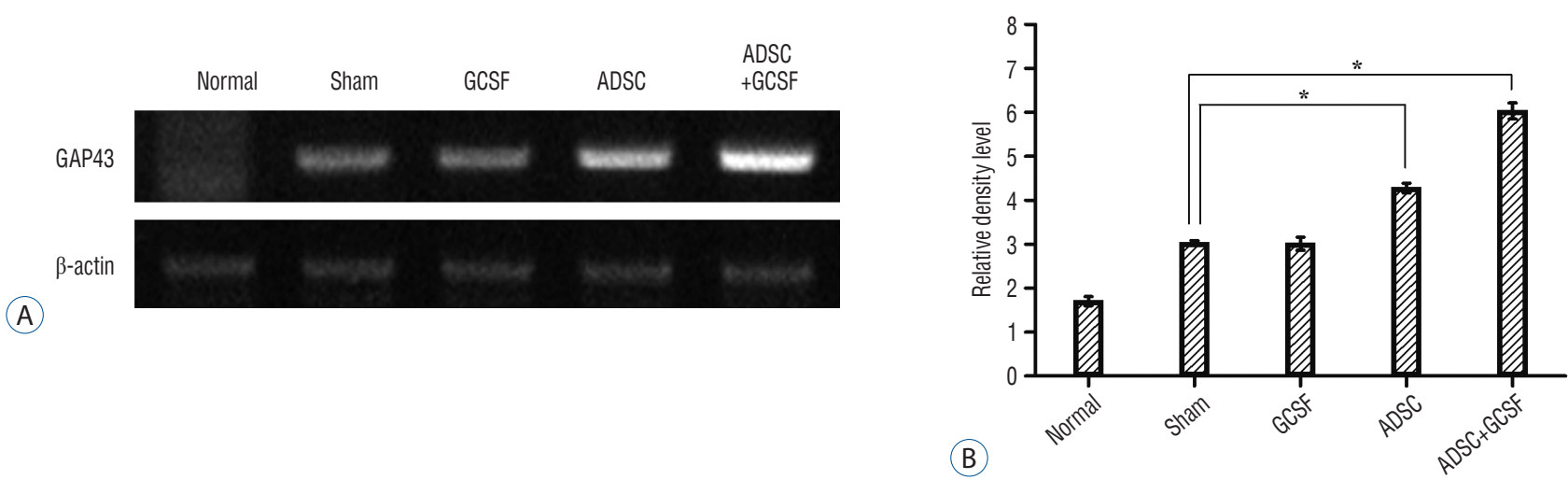

Fig. 11. RT-PCR analysis of GAP43. A : Injured epicenters of $0.5 \mathrm{~cm}$ spinal cord were extracted mRNA and analyzed by RT-PCR. B : When the band densities were converted to RDL value, the ADSC and ADSC+GCSF groups showed significantly high density than the Sham and GCSF groups. The ADSC+GCSF group showed significantly higher density than ADSC group. ${ }^{*} p<0.01$. RT-PCR : reverse transcription polymerase chain reaction, $\mathrm{RDL}$ : relative density level, ADSC : adipose-derived stem cell, GCSF : granulocyte colony-stimulating factor. 

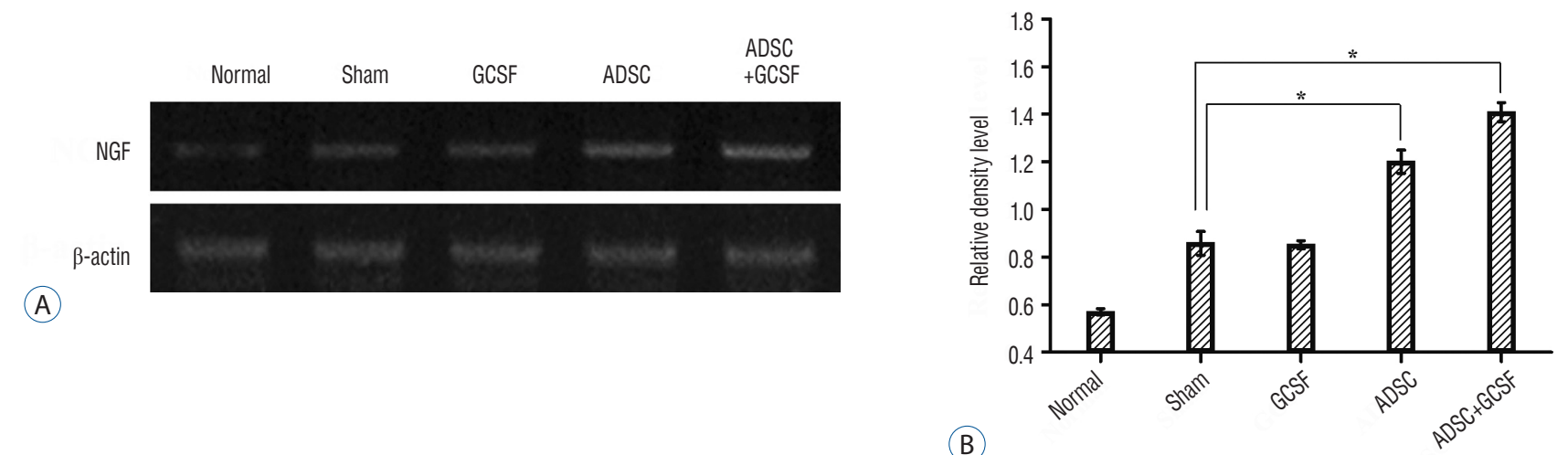

Fig. 12. RT-PCR analysis of NGF. A : Injured epicenters of $0.5 \mathrm{~cm}$ spinal cord were extracted mRNA and analyzed by RT-PCR. B : When the band densities were converted into RDL value, the ADSC and ADSC+GCSF groups showed significantly high density than the Sham and GCSF groups. The ADSC+GCSF group showed significantly higher density than ADSC group. ${ }^{*} p<0.01$. RT-PCR : reverse transcription polymerase chain reaction, RDL : relative density level, ADSC : adipose-derived stem cell, GCSF : granulocyte colony-stimulating factor.

range was confirmed to show higher expression of angiogenic cytokines, sparing of white matter and significantly greater recovery of hindlimb function after $\mathrm{SCI}^{18,47)}$.

In the studies of rodent SCI, three to seven days after SCI seem to be the optimal time window to apply cell therapy $^{14,27,3,34)}$. In addition, the effect of stem cell was demonstrated even in the chronic status of SCI in human patients ${ }^{15,30)}$. The chronic phase of SCI in rat is defined as the period since seven days after $\mathrm{SCI}^{22,31,44)}$. In this study, we intended to apply therapeutic materials in the period covering all effective time windows. Therefore, we injected GCSF and ADSCs 3, 7, and 14 days after SCI.

For immunofluorescent evaluation, we used several markers including GAP43, MAP2, and ChAT to evaluate axon regeneration and neuronal preservation. GAP43, which is expressed during the re-growth of axon growth cone membrane ${ }^{50)}$, can be utilized as an axon regeneration marker. The MAP2 which is involved in microtubule assembly, an essential step in neurogenesis, could also be utilized ${ }^{19}$. ChAT was used as an immune staining marker for motor neurons, which is synthesized within the body of a neuron and joins Acetyl-CoA to choline ${ }^{48}$. Also, we were trying to measure the quantity of neurotransmitters by the western blot method of acetylcholine receptor and serotonin transporter. Acetylcholine receptor is transmembrane receptor that responds to binding of acetylcholine which is one of the many neurotransmitters in the autonomic nervous system, but the only neurotransmitter used in the motor division of the somatic nervous system ${ }^{41)}$. In addition, serotonin transporter is an integral membrane protein that transports the neurotransmitter serotonin from synaptic spaces into presynaptic neurons ${ }^{32}$. The levels of GAP43 were found to be significantly increased in the cell injection groups (ADSC and ADSC+GCSF groups), as seen from our current immunofluorescent study, western blotting, and RT-PCR results. The presence of this protein could indicate the new growth of axons, which may have enabled the functional recovery witnessed in the behavioral tests, in response to the repeated injection of ADSCs. However, the additive effect of the GCSF on GAP43 levels was not observed to be significant because it increased both in ADSC and ADSC+GCSF groups and there was no significant difference between them like the result of BBB locomotor rating scale. The results of serotonin transporter level in western blot and the level of NGF in RTPCR were found to be increased in ADSC and ADSC+GCSF groups higher than those of Sham and GCSF groups. However, there was also no significant difference between ADSC and ADSC+GCSF group, which also implies no additive effect of combination therapy.

\section{CONCLUSION}

Therefore, in our present study, we could not find additive effects of GCSF in combined ADSCs treatment for acute SCI although GCSF with its reported functions, as we described previously, is expected to exert additive effect when working with stem cells. One previous study which evaluated the combination effect of umbilical cord blood-derived MSCs and 
GCSF on a canine SCI model also reported no beneficial effect of GCSF when treated with UBC-derived MSCs. They suspected the possibility of a down-regulation of MSCs proliferation by $\mathrm{GCSF}^{5}$ since GCSF was known to enhance stem cell damage when it combined with certain cytotoxic agents ${ }^{29)}$. However, there was no cytotoxic agent in this study and harmful effect of GCSF was also not observed. We think the results would be similar even if the GCSF had been applied in the same way as the cells because GCSF effects start from bone marrow stimulation as we mentioned above. GCSF intrathecally injected would be absorbed systemically and stimulate bone marrow. The reasons why additive therapeutic effects of these two molecules were not exerted should be investigated, and molecules other than GCSF or a modification of the methodology should be considered in further study for combination therapy with stem cells.

\section{- Acknowledgements}

This study was supported by a grant (12-176) from the Asan Institute for Life Sciences, Seoul, Korea.

This study was reviewed and approved by the IACUC Asan Institute for Life Sciences, Asan Medical Center. The committee abides by the ILAR guide (2012-02-029).

\section{References}

1. Aguilar RM, Steward 0 : A bilateral cervical contusion injury model in mice: assessment of gripping strength as a measure of forelimb motor function. Exp Neurol 221 : 38-53, 2010

2. Barry FP : Biology and clinical applications of mesenchymal stem cells. Birth Defects Res C Embryo Today 69 : 250-256, 2003

3. Basso DM, Beattie MS, Bresnahan JC : A sensitive and reliable locomotor rating scale for open field testing in rats. J Neurotrauma $12: 1-21$, 1995

4. Beveridge RA, Miller JA, Kales AN, Binder RA, Robert NJ, Harvey JH, et al. : A comparison of efficacy of sargramostim (yeast-derived RhuGMCSF) and filgrastim (bacteria-derived RhuG-CSF) in the therapeutic setting of chemotherapy-induced myelosuppression. Cancer Invest 16 : 366-373, 1998

5. Choi JS, Leem JW, Lee KH, Kim SS, Suh-Kim H, Jung SJ, et al. : Effects of human mesenchymal stem cell transplantation combined with polymer on functional recovery following spinal cord hemisection in rats. Korean J Physiol Pharmacol 16 : 405-411, 2012

6. Cizkova D, Rosocha J, Vanicky I, Jergova S, Cizek M : Transplants of human mesenchymal stem cells improve functional recovery after spinal cord injury in the rat. Cell Mol Neurobiol 26 : 1167-1180, 2006
7. Corre J, Barreau C, Cousin B, Chavoin JP, Caton D, Fournial G, et al. Human subcutaneous adipose cells support complete differentiation but not self-renewal of hematopoietic progenitors. J Cell Physiol 208 : 282-288, 2006

8. Couto PA, Filipe VM, Magalhaes LG, Pereira JE, Costa LM, Melo-Pinto $P$, et al. : A comparison of two-dimensional and three-dimensional techniques for the determination of hindlimb kinematics during treadmil locomotion in rats following spinal cord injury. J Neurosci Methods 173 : 193-200, 2008

9. Demetri GD, Griffin JD : Granulocyte colony-stimulating factor and its receptor. Blood $78:$ 2791-2808, 1991

10. Deng YB, Yuan QT, Liu XG, Liu XL, Liu Y, Liu ZG, et al. : Functional recovery after rhesus monkey spinal cord injury by transplantation of bone marrow mesenchymal-stem cell-derived neurons. Chin Med J (Engl) 118 : 1533-1541, 2005

11. Dittgen T, Pitzer C, Plaas C, Kirsch F, Vogt G, Laage R, et al. : Granulocyte-colony stimulating factor (G-CSF) improves motor recovery in the rat impactor model for spinal cord injury. PLoS One 7 : e29880, 2012

12. Furuya $T$, Hashimoto M, Koda M, Okawa A, Murata A, Takahashi $K$, et al. : Treatment of rat spinal cord injury with a Rho-kinase inhibitor and bone marrow stromal cell transplantation. Brain Res 1295 : 192-202, 2009

13. Gimble JM, Guilak F : Differentiation potential of adipose derived adult stem (ADAS) cells. Curr Top Dev Biol 58 : 137-160, 2003

14. Hodgetts SI, Simmons PJ, Plant GW : A comparison of the behavioral and anatomical outcomes in sub-acute and chronic spinal cord injury models following treatment with human mesenchymal precursor cell transplantation and recombinant decorin. Exp Neurol 248 : 343-359, 2013

15. Jeon SR, Park JH, Lee JH, Kim DY, Kim HS, Sung IY, et al. : Treatment of spinal cord injury with bone marrow-derived, cultured autologous mesenchymal stem cells. Tissue Eng Regen Med 7 : 316-322, 2010

16. Jeong JH, Lee JH, Jin ES, Min JK, Jeon SR, Choi KH : Regeneration of intervertebral discs in a rat disc degeneration model by implanted adipose-tissue-derived stromal cells. Acta Neurochir (Wien) 152 : 1771 1777,2010

17. Katz AJ, Tholpady A, Tholpady SS, Shang H, Ogle RC : Cell surface and transcriptional characterization of human adipose-derived adherent stromal (hADAS) cells. Stem Cells 23 : 412-423, 2005

18. Kawabe J, Koda M, Hashimoto M, Fujiyoshi T, Furuya T, Endo T, et al. : Neuroprotective effects of granulocyte colony-stimulating factor and relationship to promotion of angiogenesis after spinal cord injury in rats: laboratory investigation. J Neurosurg Spine 15 : 414-421, 2011

19. Kim KN, Oh SH, Lee KH, Yoon DH : Effect of human mesenchymal stem cell transplantation combined with growth factor infusion in the repair of injured spinal cord. Acta Neurochir Suppl 99 : 133-136, 2006

20. Kishk NA, Gabr H, Hamdy S, Afifi L, Abokresha N, Mahmoud H, et al. : Case control series of intrathecal autologous bone marrow mesenchymal stem cell therapy for chronic spinal cord injury. Neurorehabil Neural Repair 24 : 702-708, 2010

21. Lee HJ, Kim KS, Park IH, Kim SU : Human neural stem cells over-express- 
ing VEGF provide neuroprotection, angiogenesis and functional recovery in mouse stroke model. PLoS One 2 : e156, 2007

22. Lee KH, Suh-Kim H, Choi JS, Jeun SS, Kim EJ, Kim SS, et al. : Human mesenchymal stem cell transplantation promotes functional recovery following acute spinal cord injury in rats. Acta Neurobiol Exp (Wars) $67:$ 13-22, 2007

23. Liang $P$, Jin $L H$, Liang $T$, Liu EZ, Zhao SG : Human neural stem cells promote corticospinal axons regeneration and synapse reformation in injured spinal cord of rats. Chin Med J (Engl) 119 : 1331-1338, 2006

24. Lim JH, Byeon YE, Ryu HH, Jeong YH, Lee YW, Kim WH, et al. : Transplantation of canine umbilical cord blood-derived mesenchymal stem cells in experimentally induced spinal cord injured dogs. J Vet Sci 8 : 275-282, 2007

25. Mukaetova-Ladinska EB, Andras A, Milne J, Abdel-All Z, Borr I, Jaros $E$, et al. : Synaptic proteins and choline acetyltransferase loss in visual cortex in dementia with Lewy bodies. J Neuropathol Exp Neurol 72 : 53-60, 2013

26. Murphy JM, Fink DJ, Hunziker EB, Barry FP : Stem cell therapy in a caprine model of osteoarthritis. Arthritis Rheum 48 : 3464-3474, 2003

27. Nandoe Tewarie RD, Hurtado A, Ritfeld GJ, Rahiem ST, Wendell DF, Barroso $M M$, et al. : Bone marrow stromal cells elicit tissue sparing after acute but not delayed transplantation into the contused adult rat thoracic spinal cord. J Neurotrauma 26 : 2313-2322, 2009

28. Nishi RA, Liu H, Chu Y, Hamamura M, Su MY, Nalcioglu O, et al. : Behavioral, histological, and ex vivo magnetic resonance imaging assessment of graded contusion spinal cord injury in mice. J Neurotrauma 24 : 674-689, 2007

29. Pal R, Venkataramana NK, Bansal A, Balaraju S, Jan M, Chandra R, et al. : Ex vivo-expanded autologous bone marrow-derived mesenchymal stromal cells in human spinal cord injury/paraplegia: a pilot clinical study. Cytotherapy $11: 897-911,2009$

30. Park JH, Kim DY, Sung IY, Choi GH, Jeon MH, Kim KK, et al. : Longterm results of spinal cord injury therapy using mesenchymal stem cells derived from bone marrow in humans. Neurosurgery 70 : 1238-1247; discussion 1247, 2012

31. Parr AM, Kulbatski I, Tator $\mathrm{CH}$ : Transplantation of adult rat spinal cord stem/progenitor cells for spinal cord injury. J Neurotrauma 24 : 835845, 2007

32. Pitzer C, Klussmann S, Kruger C, Letellier E, Plaas C, Dittgen $T$, et al. : The hematopoietic factor granulocyte-colony stimulating factor improves outcome in experimental spinal cord injury. J Neurochem 113 : 930942, 2010

33. Quertainmont R, Cantinieaux D, Botman O, Sid S, Schoenen J, Franzen R : Mesenchymal stem cell graft improves recovery after spinal cord injury in adult rats through neurotrophic and pro-angiogenic actions. PLoS One 7 : e39500, 2012

34. Ritfeld GJ, Nandoe Tewarie RD, Vajn K, Rahiem ST, Hurtado A, Wendell $D F$, et al. : Bone marrow stromal cell-mediated tissue sparing enhances functional repair after spinal cord contusion in adult rats. Cell Transplant 21 : 1561-1575, 2012

35. Rodbell $\mathrm{M}$ : Metabolism of isolated fat cells. I. Effects of hormones on glucose metabolism and lipolysis. J Biol Chem 239 : 375-380, 1964

36. Roussos I, Rodriguez M, Villan D, Ariza A, Rodriguez L, Garcia J : Development of a rat model of spinal cord injury and cellular transplantation. Transplant Proc 37 : 4127-4130, 2005

37. Ruan H, Zarnowski MJ, Cushman SW, Lodish HF : Standard isolation of primary adipose cells from mouse epididymal fat pads induces inflammatory mediators and down-regulates adipocyte genes. J Biol Chem $278: 47585-47593,2003$

38. Schaffler A, Buchler C : Concise review: adipose tissue-derived stromal cells--basic and clinical implications for novel cell-based therapies. Stem Cells $25: 818-827,2007$

39. Scheff SW, Rabchevsky AG, Fugaccia I, Main JA, Lumpp JE Jr : Experimental modeling of spinal cord injury: characterization of a forcedefined injury device. J Neurotrauma 20 : 179-193, 2003

40. Shin DA, Kim JM, Kim HI, Yi S, Ha Y, Yoon DH, et al. : Comparison of functional and histological outcomes after intralesional, intracisternal, and intravenous transplantation of human bone marrow-derived mesenchymal stromal cells in a rat model of spinal cord injury. Acta Neurochir (Wien) 155 : 1943-1950, 2013

41. Shyu WC, Lin SZ, Yang HI, Tzeng YS, Pang CY, Yen PS, et al. : Functional recovery of stroke rats induced by granulocyte colony-stimulating factorstimulated stem cells. Circulation 110 : 1847-1854, 2004

42. Sofroniew MV, Howe CL, Mobley WC : Nerve growth factor signaling, neuroprotection, and neural repair. Annu Rev Neurosci 24 : 1217 1281, 2001

43. Suh HI, Min J, Choi KH, Kim SW, Kim KS, Jeon SR : Axonal regeneration effects of Wnt3a-secreting fibroblast transplantation in spinal cordinjured rats. Acta Neurochir (Wien) 153 : 1003-1010, 2011

44. Sykova E, Jendelova P, Urdzikova L, Lesny P, Hejcl A : Bone marrow stem cells and polymer hydrogels-two strategies for spinal cord injury repair. Cell Mol Neurobiol 26 : 1113-1129, 2006

45. Thuret S, Moon LD, Gage FH : Therapeutic interventions after spinal cord injury. Nat Rev Neurosci 7 : 628-643, 2006

46. Tobias CA, Han SS, Shumsky JS, Kim D, Tumolo M, Dhoot NO, et al. : Alginate encapsulated BDNF-producing fibroblast grafts permit recovery of function after spinal cord injury in the absence of immune suppression. J Neurotrauma 22 : 138-156, 2005

47. Urdzikova L, Jendelova P, Glogarova K, Burian M, Hajek M, Sykova E : Transplantation of bone marrow stem cells as well as mobilization by granulocyte-colony stimulating factor promotes recovery after spinal cord injury in rats. J Neurotrauma 23 : 1379-1391, 2006

48. Weaver CH, Buckner CD, Longin K, Appelbaum FR, Rowley S, Lilleby K, et al. : Syngeneic transplantation with peripheral blood mononuclear cells collected after the administration of recombinant human granulocyte colony-stimulating factor. Blood 82 : 1981-1984, 1993

49. Wright KT, El Masri W, Osman A, Chowdhury J, Johnson WE : Concise review: Bone marrow for the treatment of spinal cord injury: mechanisms and clinical applications. Stem Cells 29 : 169-178, 2011

50. Zhou Z, Chen Y, Zhang H, Min S, Yu B, He B, et al. : Comparison of mesenchymal stromal cells from human bone marrow and adipose tissue for the treatment of spinal cord injury. Cytotherapy 15 : 434-448, 2013 